Article

\title{
The Future of Islamism through the Lens of the Past
}

\author{
Marc Lynch
}

check for

updates

Citation: Lynch, Marc. 2022. The

Future of Islamism through the Lens of the Past. Religions 13: 113.

https://doi.org/10.3390/rel13020113

Academic Editors: Bjørn Olav Utvik and Brynjar Lia

Received: 15 December 2021

Accepted: 18 January 2022

Published: 24 January 2022

Publisher's Note: MDPI stays neutral with regard to jurisdictional claims in published maps and institutional affiliations.

Copyright: (C) 2022 by the author. Licensee MDPI, Basel, Switzerland. This article is an open access article distributed under the terms and conditions of the Creative Commons Attribution (CC BY) license (https:// creativecommons.org/licenses/by/ $4.0 /)$.
Department of Political Science, The George Washington University, Washington, DC 20052, USA; mlynch@gwu.edu

\begin{abstract}
Islamist movements today face perhaps their most difficult conditions in decades. After seizing political openings after the Arab uprisings, the Muslim Brotherhood and other Sunni political Islamist organizations have suffered from military coups, electoral defeats, social and political polarization, and extreme repression. This is not the first time they have faced such catastrophic conditions, however, and historically Islamist organizations have proven to be resilient and able to return to public life. This article examines the history of Islamist movements in the Middle East recovering from extreme setbacks in order to identify nine key mechanisms that facilitated those rebounds and then considers which of those factors might be operative today. It concludes that many of those factors are less available than in the past, but that the global turn toward populism, the persistent governance failures of Arab states, and the adaptability of Islamists create greater opportunities for recovery than might initially appear plausible.
\end{abstract}

Keywords: Islamism; Muslim Brotherhood; jihad; populism; Middle East; Ennahda

\section{Introduction}

Political Islam is at perhaps its lowest ebb since the 1960s. Since the 2011 Arab uprisings, Sunni Islamist movements across the Arab Middle East have seen the fruits of their electoral victories vanish into social polarization, repression, coups, and international isolation (Lynch 2016a; Lynch and Schwedler 2020). In the near term, it seems likely that Islamist movements across the spectrum will continue to recede in cultural, political, and societal influence (Ardovini and Biagini 2021). Their retreat from the public realm may lead to misleading conclusions about their longer term political viability, however. Most Middle Eastern societies remain culturally conservative, with religious symbols retaining great power and resonance. The disastrous political and economic conditions across the region make the recurrence of various forms of political mobilization and instability nearly inevitable. This is a populist era, and Islamist movements are traditionally well positioned for such political contexts.

This is not the first time that Islamist movements have suffered catastrophic setbacks in the face of state repression or popular rejection. Islamists have proven their ability to rebound quickly from devastating conditions. Egypt in the 1970s is the prototypical example. Nasserist repression of the Brotherhood in the 1950s and 1960s had nearly destroyed the organization, while religious trends had been pushed to the margins of political and cultural life. It did not take long for the Brotherhood to re-emerge when Sadat brought the Islamists out of the prisons and encouraged their political return to serve as a counterweight to Nasserists and the Left. In Tunisia, the Ennahda movement had been largely destroyed by the Ben Ali regime in the 1990s and 2000s but returned to dominate elections in 2011 despite lacking social services, public presence, or robust organization (Wolf 2017; McCarthy 2018b). The Syrian Muslim Brotherhood took a leading role in the political opposition in 2011 despite having been crushed and driven into exile by the Assad regime in the early 1980s (Lefèvre 2013; Conduit 2020). Iraqi Islamists took a lead role in Sunni politics after 2003 despite having been repressed and feared by Saddam Hussein's regime (Helfont 2018). 
The lessons of the past are mixed. Islamist movements today lack several key advantages which facilitated those earlier revivals. There is no strong Left or populist movement against which regimes might find Islamists a useful weapon; on the contrary, it is still the Islamists who are viewed as the primary threat. Political polarization and intense demonization have badly damaged the reputation for integrity and competence that they once enjoyed (Cammett and Luong 2014; Masoud 2014). The Gulf states that financed the resurgence of Islamism in the 1970s and 1980s through direct assistance and through large-scale labor remittances are now deeply hostile to Islamism and likely determined to block such financial flows (Medani 2021). States such as Egypt are now less willing to outsource social services or to allow Islamists to fill areas of limited state capacity where they might win over potential recruits. Most surviving leaders and veteran members of Egypt's Muslim Brotherhood are in prison or exile, making it difficult to rebuild organic connections with society.

Nonetheless, while political Islam as a project is in worse shape than many observers appreciate, it also has better - though far from certain — prospects for revival. The ongoing failures of governance and economic provision across much of the region ensure a deep reservoir of discontent. In many Arab countries, Islamist movements grew and thrived by filling the gaps in social service provision as states receded. The depth of their repression in countries such as Egypt now puts the pressure of providing such services squarely on the state, which is manifestly incapable of doing so. Most importantly, however, global conditions are highly favorable to populism in its various manifestations, a trend from which Islamists have historically been able to profit. While their unpopularity is very real and deep, political polarization actually makes it easier to rebuild in counter-publics and compartmentalized spaces where appealing to enemies is neither necessary nor encouraged. A revival on these terms would mean an Islamism that looks very different from its previous incarnation: more insular, with less public presence and political participation, and integrating previously distinctive ideological strands of the broader Islamist milieu.

This essay proceeds as follows. First, I look at the evolution of the broader Islamist milieu since the 2011 uprisings, emphasizing the eroding distinctions between previously quite distinct trends. Second, I detail the extent and magnitude of the current catastrophic situation for most traditional political Islamist organizations. Third, I look to the history of Islamist organizations recovering from existential setbacks, drawing out a number of critical lessons. Finally, I consider whether and how the factors that allowed those earlier revivals are likely to be applicable in the coming decade.

\section{The Current Catastrophe of Political Islam}

Islamism manifests in many forms, from Salafist movements focused on religious practice to violent Salafi-jihadist movements. This essay focuses on political Islam, the family of Sunni Islamists loosely associated with the Muslim Brotherhood tradition. These movements and parties typically share a set of ideological referent points and organizational forms. They are typically engaged in formal institutional politics where permitted, contesting elections and sitting in Parliaments or syndicate boards. They typically maintain a public presence, whatever their legal status, offering social services and working to Islamicize the public sphere. In addition, they typically eschew violence, differentiating themselves from violent extremists by offering a rhetoric of moderation. The relationship among these parties and movements is one of family type and milieu, with at best a nominal international organization linking them together. The analysis in this paper focuses on these parties and movements, such as Muslim Brotherhood organizations in Egypt and Jordan, the Ennahda Movement in Tunisia, and Morocco's Party of Justice and Development. The Palestinian Hamas emerged from the Muslim Brotherhood but has evolved into a parastatal organization governing Gaza that embraces violent resistance. The scope of the analysis does not extend to non-Arab Islamists, violent Salafi-jihadist movements, proselytizing Salafi movements or Shi'a Islamists, but at the end of the essay I return to them for comparative purposes. 
Political Islamist movements seized the opportunities offered by the Arab uprisings. Islamist organizations emerged from the shadows of repression, contested elections, joined deliberations over new constitutions, and seemed poised to dominate the future. As a result, they experienced catastrophic setbacks in almost every country where they bid for power. In Egypt, the Parliamentary and Presidential electoral victories of 2011-2012 that brought the Muslim Brotherhood formally into power ended in disaster (Pahwa 2017). Their attempts to govern provoked a widespread public backlash driven by fears over Islamist domination, resistance by the entrenched institutions of the military and the state, and ultimately an externally supported military coup which resulted in repression unseen since the 1950s (Al-Anani 2015). Their formal institutional presence in Egyptian society has been eradicated, accompanied by ongoing propaganda campaigns relentlessly driving home their demonization as fundamentally un-Egyptian extremists and terrorists. The degree of trauma inflicted upon the Muslim Brotherhood organization and members, from the August 2013 massacre of Islamist protestors to the mass arrests and displacement of members, can hardly be overstated (Willi 2021; Matthies-Boon 2017).

The setbacks go beyond Egypt. In Tunisia, Ennahda's efforts to avoid the Egyptian model led it to enter into a grand coalition with its anti-Islamist rivals (McCarthy 2018b). This left Ennahda widely feared and hated by non-Islamists, blamed for political and economic paralysis, and increasingly viewed as corrupt and elitist. In 2021, its political role also ended in a coup, this time by President Kais Saied's dissolution of Parliament and suspension of the constitution. In Morocco, the Party of Justice and Development (PJD) was allowed to form consecutive governments by the monarchy, which over time similarly led it to be blamed for continuing economic and political failures over which it had little effective control. In elections this year, however free or fair one might consider them, the PJD was swept from its Parliamentary majority with the worst electoral performance of its existence. In Jordan, the Muslim Brotherhood's long time status as the leading political opposition movement has been degraded by years of regime pressure, including the division of the organization and seizure of its assets; it has played little meaningful role in the ongoing political mobilization there (Wagemakers 2021). Libyan Islamists could not dominate elections and ended up divided across a polarizing and fragmented political landscape; Sunni Islamist parties in Iraq have seen their political role dissipate; Syrian Muslim Brothers saw their role in the political opposition prove divisive and contribute to its failure; Islamists in Sudan were targeted by the 2018 revolution for their association with the Bashir regime; Islamists played little role in Algeria's Hirak mobilization because of that country's traumatic history with political Islam.

The political scorecard above does not do full justice to the difficult position of political Islam today. The authoritarian backlash against the Arab uprisings has closed down meaningful opportunities for electoral participation, even if popularity could be rebuilt. At the international level, political Islam has seen several critical changes that have deprived it of key power and legitimacy resources. Saudi Arabia's turn against the Muslim Brotherhood, including the joint designation of it as a terrorist organization, has shut off key funding streams that were central to the power and evolution of Islamist organizations. The UAE, of course, has long been fiercely hostile to the Muslim Brotherhood. The proxy wars that erupted across the region following 2011 turned the Muslim Brotherhood into a key symbolic and political battleground, with the UAE and Saudi Arabia intervening across the political, economic, and cultural spectrum against political Islamists in Egypt, Tunisia, Libya, and beyond. Qatar and Turkey offered support to such organizations, partly for ideological reasons and partly out of their availability via the competitive logic of proxy warfare. Their support to Islamists only politicized them further, with the 2017 blockade of Qatar centering the issue and often alienating domestic publics who came to view Islamists as Qatari or Turkish proxies. Since the 2021 tentative resolution of the Qatar crisis and the Gulf's quiet efforts to rebuild relations with Turkey, Muslim Brotherhood-affiliated organizations have lost much of their previously available external support and safe haven. Nor can they easily turn to Iran, as might have once been possible under the rubric of 
the "Axis of Resistance"; decades of sectarianization and especially the toxic legacies of the Syrian civil war make it ideologically extremely difficult for the Brotherhood to align effectively with Iran.

Organizationally, Brotherhood organizations are shells of their former selves. In Egypt, little remains of the Muslim Brotherhood's dense, sprawling organizational infrastructure (Ardovini 2021). Post-2013 repression has seen tens of thousands of its members and leaders imprisoned or killed. Most of the organizational assets, and those of its members, have been seized by the state, while its clinics and other social services have been shuttered or put under non-Islamist management. Its hierarchy and discipline have also been shattered, with rival factions publicly advancing claims to the organization and widespread defections by its members. Without its public presence, deep and disciplined membership, social services, or political party, the remnants of the Egyptian Brotherhood bear little resemblance to the political and social powerhouse of previous decades (Lynch 2016a). Individual members are traumatized, rethinking their commitments in exile and many retreating from political engagement (Matthies-Boon 2017; Menshawy 2021). Tunisia's Ennahda may be moving in the same direction since President Kais Saied's coup, which dissolved Parliament and suspended the constitution, though this remains openly contested at this point. Jordan's Muslim Brotherhood is similarly divided and degraded organizationally (Wagemakers 2020). Any adaptations or revival will require rebuilding these organizations, not simply activating latent networks and mobilizing extant resources.

Socially, the regional and national polarization has left Islamists widely demonized, indeed pariahs, in much of the region. The scale and scope of the polarization around Islamism after 2011 has been surprising and is not simply an artifact of effective regime or Gulf propaganda. The prospect of Islamist governance triggered deep, existential horror among key social classes across the region, including elites, women, and certain youth sectors, which gave counterrevolutionary forces much to work with. The depth of this anti-Islamist backlash in Egypt and Tunisia, especially, has left them profoundly isolated politically. In Egypt, it erased decades of the long, patient cultivation of public opinion, its reputation for integrity and moderation, and its availability as a political ally. In Tunisia, it overwhelmed the intensive efforts by Ennahda leader Rached Ghannouchi to discard the Islamist label and to disarm political fears by governing within a grand coalition and exercising self-restraint in competing for Parliamentary seats or cabinet positions (Daadaoui 2021). While these anti-Islamist currents were certainly amplified and stoked by social media and regime propaganda, they have clearly taken deep root and will act as a roadblock to any easy Islamist return to the political arena. Given the reputational foundation of the Islamist political advantage, the widespread hostility strikes at the core of their electoral and organizational power (Cammett and Luong 2014).

Ideologically and strategically, then, political Islam has in many ways run out of steam. Its guiding political strategy for decades had been political participation and the patient transformation of society from below. For members of those organizations, the fruits of moderation and participation have been death, destruction, and despair. It is difficult to see how any Muslim Brotherhood organization can again sell to its members the argument for moderation and peaceful political participation, given the aftermath of 2011 (Schwedler 2011; Pahwa 2017; Lynch and Schwedler 2020). A return to proselytizing and apolitical religious and social work might offer an alternative, but this too will be a difficult sell for younger cadres who expect to see political responses.

The commitment to nonviolence, a key marker distinguishing political Islamists from their jihadist rivals, has been severely tested by the coups and repression after 2011. The energies unleashed by their mobilization in support of the Syrian jihad and the early successes of the Islamic State, combined with the litany of setbacks for political Islam described above, tilted the ideological argument in favor of the jihadists long before the Taliban's victory in Afghanistan added an additional jolt. It is an intriguing testimony to the ideological and organizational discipline of the Muslim Brotherhood that so few Egyptian members have thus far turned to violent jihad despite the ideological and political 
upheavals and organizational collapse (Al-Anani 2019; Fahmi 2017). It seems unlikely that this residual ideological commitment can continue without continuous active socialization, a capable organization, or a viable strategy.

Finally, there is anecdotal evidence and some survey research showing declining religiosity among certain segments of Arab youth, which could perhaps signal generational change away from Islamist solutions (The Economist 2019). Islamist activism, at least in the Brotherhood variety, is no longer cool, and older trends towards post-Islamism among younger Arabs may continue to evolve into novel forms of religious expression (Bayat 2013). Still, against this should be set the growing role of Salafi Islamists across much of the region and their continuing presence in public life and the economy. If there were truly a societal cultural backlash against religious movements, presumably the Salafis would be affected as well. For the most part, they do not seem to be.

\section{Historical Drivers of Islamist Revival}

Islamist movements and insurgencies alike have proven to be remarkably resilient. Egypt's Muslim Brotherhood came back in the 1970s after decades of harsh repression. Tunisia's Ennahda returned after 2011 to dominate elections. Syria's Muslim Brotherhood regrouped abroad after the Hama massacre and took a key role in the political leadership of the 2011 uprising. Iraq's Muslim Brotherhood survived Saddam Hussein's repression to join the leadership and represent the Sunni community following the 2003 invasion. The Islamic State in Iraq survived the "surge" and its near total defeat in 2008 to regroup and emerge even more powerful and establish the Islamic State less than a decade later. How did these Islamist movements revive?

A rich new literature offers clues. While each country's experience is different, there are some common themes.

First, political adaptability. Islamists took advantage of political openings, economic crisis, social need, and the degradation of state capacity. In Egypt, for instance, Sadat's economic liberalization policies created significant economic hardship, while his privatization created a need for independently provided social services. The Muslim Brotherhood rebuilt in part through filling the social service spaces that the Egyptian state vacated, which both provided a service to the state and embedded the organization deeply and positively within middle class urban society. The generation of leaders who experienced Nasser's repression emerged as highly cautious and pragmatic, averse to direct confrontation with the regime, and keen to demonstrate their moderation even where challenged by less patient younger members or by radical competitors (Nugent 2020; Willi 2021). In other contexts, Islamists found ways to make themselves useful to regimes. Morocco's PJD agreed to form successive governments after winning elections in 2011, serving to demobilize key parts of the opposition protest coalition and legitimize the new constitutional reforms. Bahrain's Islamists helped the monarchy survive the 2011 mass uprising, which in turn protected it against the broader Gulf-led offensive against the Muslim Brotherhood. Even the Algerian Muslim Brotherhood found a way back to a public presence in the 2000s by offering a safe, even tame, Islamist party that could be held up as a symbol of reconciliation following the Black Decade of insurgency and civil war.

Second, trust networks and reputational advantages. Islamist movements could rely on highly developed networks of trust and reputational advantages rooted in their collective identity, religious messaging, and social presence. In Tunisia, for instance, even after Ennahda suffered brutal repression, with much of its leadership driven into exile or imprisoned, their former members were known and respected within their communities (McCarthy 2018a; Wolf 2017). Membership in Islamist organizations such as the Muslim Brotherhood or Ennahda involved not only collective action but also the cultivation of a strong collective identity (Al-Anani 2016). Positive reputational advantages accrued through social service provision, even where not explicitly branded by the organization (Brooke 2018), and the networks of trust extended to the transnational level, allowing for dis- 
tinct advantages in steering remittances and Gulf investment towards Islamist institutions and networks (Medani 2021).

Third, organizing in exile. Diaspora offered opportunities to engage in new forms of political organizing, ideological revision, and long-term strategic thinking. In Syria and Iraq, Muslim Brothers forced abroad operated within exile political circles, earning them pride of place as representatives of the Sunni community. The Iraqi Islamic Party took such a role in the post-2003 Iraqi government, brokering its externally appointed position into powerful patronage networks that built a political base from scratch. The Syrian Muslim Brotherhood used backing from Qatar and Turkey, as well as their own organizational skills, to take a disproportionately large role in the Syrian National Council formed to coordinate and ostensibly lead the 2011 uprising against Bashar al-Assad. Tunisia's Ennahda took advantage of their extended exile to build strong relations with other political movements, which could then be mobilized during the transition to maintain some degree of political cooperation and consensus (Cavatorta and Merone 2013).

Fourth, media and messaging. Even where organization on the ground was difficult and weak, Islamist organizations maintained robust media presences. The launch of al-Jazeera gave Islamists a welcome alongside other political trends, which evolved in 2011 as a near hegemony over the platform. Islamists were early and successful adopters of new media forms, from magazines and cassette tapes in the 1970s to websites and social media in more recent years. Their ability to widely circulate their messages through both physical mosque-based networks and online religious and political networks kept their message prominent.

Fifth, the advantages of opposition. By remaining outside of ruling coalitions and elite patronage networks, they could sustain a reputation for independence and integrity that few co-opted political movements or parties could manage. With no responsibility for political or economic outcomes, they could present a message demanding democracy and accountability while remaining vague about their own alternative plans.

Sixth, strategic moderation. Political Islamist organizations could benefit strategically from the rise of violent forms of jihadist insurgency and transnational terrorism. The existence of violent jihadists offered the opportunity to articulate a nonviolent alternative, which made them appear more acceptable to mainstream and policy audiences. To the extent that the Brotherhood presented itself as a firewall against radicalization and a formidable obstacle to jihadist rivals, they made themselves strategically useful to regimes (Lynch 2010, 2016b). This strategic moderation went beyond performative acts such as denouncing the September 2001 attacks on the United States or a succession of local acts of terrorism. It also involved preventing radicalization by dominating Islamic spaces such as mosques and by holding its own members within its own organizational space and denying jihadists a valuable potential pool of recruits.

Seventh, organizational strength. Muslim Brotherhood organizations were optimized to survive under repression, with a rigidly hierarchical leadership structure combined with a highly decentralized cell structure in which members primarily interacted with small families (cells). This allowed for a high degree of socialization and indoctrination of individual members and the ability to mobilize quickly and coherently when called upon to act. This organizational capacity proved resilient even under extreme pressure, with a skeleton in place even with very few active cadres working underground to keep the organization alive (Wolf 2017; McCarthy 2018a; Willi 2021).

Eighth, financing. The material dimension of the Islamist revival should not be overlooked. Islamists in the 1970s and 1980s were able to ride the oil boom to great advantage (Medani 2021). Oil wealth flowed out into Islamists around the region through multiple channels: labor remittances, Islamic banks, direct Saudi patronage of mosques and religious materials. By the 1990s, Egypt's Muslim Brotherhood and Salafis alike had built robust parallel economic sectors, which could be used to fund their political activities and to support their social service provisions. 
Ninth, ideological revisions. Islamist organizations that faced severe repression in most cases underwent internal processes of ideological adaptation, which positioned them to take advantage of opportunities for revival. In Egypt, the Muslim Brotherhood under Hassan Hudaybi's guidance moved to publicly repudiate the radical doctrines espoused by Sayyid Qutb and his followers, thus presenting themselves as both palatable to Anwar Sadat's regime and a useful counterweight to more radical Islamist trends (Zollner 2008). Egypt's Al-Gamaa al-Islamiyya underwent ideological revisions from prison which led to their rehabilitation into public life (Ashour 2009; Drevon 2015; Hwang 2018). Syria's Muslim Brotherhood in exile after 1982 revised its ideology and worked to build connections to other opposition trends abroad (Lefèvre 2013; Conduit 2020). Tunisia's Ennahda similarly reframed its oppositional activity around democracy and human rights, seeking coalitions with non-Islamist trends for a broad front against the Ben Ali regime (Wolf 2017; McCarthy 2018b).

\section{Prospects for Islamist Revival}

Current conditions are certainly bleak, but Islamism, both ideologically and organizationally, has proven resilient over the decades and has rebounded from periods of extreme repression and marginalization before. The previous section identified nine factors that arguably contributed to previous historical episodes of Islamist revival. How will each of those nine factors potentially operate in the near to medium term horizon?

First, adaptability. The Middle East remains a deeply troubled context, with cascading economic, political, and social crises exacerbated by COVID, which seem likely to present myriad opportunities for political instability and popular mobilization. Anti-Islamist autocrats are banking on the sustainability of the post-2013 authoritarian restorations, so that no successor to the Muslim Brotherhood will find the opportunity to re-emerge. To the extent that political instability and popular mobilization in response to economic and political grievances loom, it seems more than plausible that Islamists will adapt to those conditions and find ways to act effectively.

Second, reputation and trust. Islamists have long been able to generate compelling messages rooted in Islamic symbols and cultural resonance, which have given them observable political advantages (Cammett and Luong 2014). Many of those advantages have been degraded by the last decade's turmoil, but not all. Most Arab societies remain conservative and attuned to religious and moral appeals, even if the Brotherhood itself has seen its reputation decimated. Mosques continue to offer focal points for engagement, organization, recruitment, and dissemination of messages. While there has been significant media attention to rising trends such as atheism or secularization, there is not much systematic evidence to support the idea of large-scale societal or generational change (The Economist 2019). Anti-Islamism and youth political culture have sparked some performative antipathy to religion, but this will be a superficial and transient phenomenon. Regimes such as Egypt's, Morocco's, Syria's, and the UAE's have generally sought to promote alternative, non-political Islamic authorities rather than denigrate Islam per se. Islamists seeking a road back politically will still be able to draw on religious symbols but will have far less ability to call on reservoirs of personal or organizational reputation. They also face stronger competitors within the Islamist milieu, from politically engaged Salafis to reconfigured and more empowered state Islamic sectors.

Third, exile. The Muslim Brotherhood abroad today faces a different environment than the earlier generation of Syrian, Tunisian, and Egyptian Brothers forced abroad (The Gulf, particularly Saudi Arabia, no longer offers a safe haven with ample employment and fundraising opportunities, robust religious networks and institutions, and tacit state support (Lacroix 2011)). Deep mistrust emanating from the polarization of the last decade makes it more difficult for Brothers to build relationships or opposition coalitions with nonIslamists. Brotherhood exiles relocating to the few remaining options such as Turkey, Qatar and Sudan find themselves at risk of being deployed as proxies or vulnerable to changes in the foreign policies or even regimes of their hosts. The Egyptian Muslim Brotherhood, for 
instance, in late 2021 found its reorganized presence abroad endangered by the unexpected reconciliation between the UAE and both Turkey and Qatar. The experience of exile has, instead, produced notable — and historically unusual—rifts between leaders attempting to reconstitute abroad and cadres still present on the ground, with open fragmentation, divides over strategy, and individual drifting away from the organization (Ardovini 2021).

Fourth, media. At one level, polarization and the weaponization of online platforms would suggest limitations of Islamist ability to duplicate their earlier success at dominating online spaces and the political public sphere. Polarization and failure have led to what Mellor (2021) has called a fragmentation of the Brotherhood's faith brand. Here, however, the prospects may be brighter for Islamists than they might initially appear. Highly segmented social media and polarization may limit the ability of Islamists to reach out to mass publics as they once did, but they have the same effect on everyone else. Leftists, liberals, and other political trends face similar constraints, while often enjoying fewer inherent advantages. What is more, the relatively homogenous and insular echo chambers that such media fragmentation encourages-as well as the mutual hostility inherent in social polarization-can help with rapidly building shared identity and common narratives. In a polarized political arena, more motivated and interconnected trends have an advantage. Islamists who have suffered extreme repression and feel marginalized and demonized in newly constituted regimes are likely to use social media spaces to cultivate and nurture identities rooted in their shared suffering. If Islamists are able to take advantage of political openings as suggested above, they may, despite everything, retain key advantages over divided and less mobilized rivals.

Fifth, the advantages of opposition. the experience of the last decade generally shows that Islamists do poorly in power, in contrast to the decades of experience showing they do well in opposition. The Egyptian Muslim Brotherhood failed in governance most spectacularly. Perhaps more telling is that in both Tunisia and Morocco, a leading role in government rapidly eroded the reputation of Islamist movements for integrity, efficiency, and competence (Brooke 2018). Their collapsing fortunes were not solely due to polarization, but also because they came to be seen as normal politicians, corrupt and unaccountable and responsible for economic and governance failures they could not fix. This is a story familiar from Turkey, where Erdogan's AKP has evolved from a moderate Islamist party into a fairly conventional corrupt, autocratic ruling party with more a cult of personality and an insular elite than an Islamist movement. The implication of this is that being forced back into opposition could become a blessing in disguise for these movements, allowing them to move back into a position where they can rebuild their popular credentials and focus popular anger on the non-Islamists in power. As the passions and hatreds of the post2011 era fade in public memory, their built-in advantages over other potential opposition movements may well come back into play.

Sixth, strategic moderation. Over the last decade, the UAE, Saudi Arabia, Egypt, and others have pushed an ideological offensive labeling the Muslim Brotherhood a terrorist organization and highlighting its radicalism. This sustained propaganda campaign, combined with the very real political polarization across the region, has badly damaged the ability of the Brotherhood and other Islamist organizations to position themselves as a moderate alternative. As noted above, Islamists themselves have struggled to sustain commitment to nonviolence and gradualist politics in the face of severe repression and political failure. The blurring of the divisions between Islamist types complicates efforts to deploy strategic moderation to reclaim a space in public life.

Seventh, organizational capacity. Here, there has been very significant degradation, but it varies by case and is not necessarily more so than in the earlier eras (Ardovini 2021; Al-Anani 2019). The Egyptian Muslim Brotherhood has clearly suffered the greatest degree of organizational disintegration. The killing, arrest, and exile of tens of thousands of members, the confiscation of vast swathes of its financial and infrastructural assets, and constant regime pressure have left the Egyptian Brotherhood barely a shell of its formidable former self. Still, historical experience shows that the strong socialization 
of its cadres, as well as the strong trust networks binding members, can substitute for formal organization (Zollner 2019). There has been far less of a turn to violence against the regime by aggrieved Brothers than one might have expected, for instance (Fahmi 2017). Beyond Egypt, the degree of organizational degradation varies widely. Jordan's Muslim Brotherhood has been riven by major divisions and asset losses (such as the Islamic Hospital in Amman), encouraged by the state but rooted in its own internal ethnic and political divides (Wagemakers 2021). Tunisia's Ennahda and Morocco's PJD, by contrast, have not experienced significant organizational losses to match their political setbacks. Despite the terrorism designation pushed by Saudi Arabia and the UAE, Brotherhood branches in Bahrain and Kuwait continue to operate as normal.

Eighth, financing. The designation of the Muslim Brotherhood as a terrorist organization by multiple Gulf states, including Saudi Arabia, has dramatically cut off one of the key sources of financing for Islamists in the earlier eras. Official financial support flows, if it does, to Salafi organizations, which have largely modeled fealty to regimes. Labor remittances will not likely ever return to previous levels, nor will they disproportionately benefit Islamist movements. Since the coup, Egypt's regime has confiscated most of the assets and wealth of the Brotherhood, with no prospect of their return. There are still some avenues for external financial support, primarily Qatar and Turkey, but the choking off of once prodigious financial flows from the Gulf into Islamist networks does undermine prospects for revival.

Ninth, ideological revisions. There is significant rethinking going on at the individual level among the ranks of Islamists, but there have not yet been significant signs of fundamentally new directions (Ardovini 2021; Al-Anani 2019). Organizations remain torn between older leaders bent on preserving and restoring the institutions as they once existed, and younger cadres seeking to learn from their mistakes. Some of those younger Islamists are disengaging from their organizations, seeking new identities and strategies (Menshawy 2021), but it is unclear where those revisions might lead. The most ambitious effort in this direction came from Rashid Ghannouchi and Ennahda, which ostentatiously relabeled itself as a party of Muslim Democracy rather than of political Islam (Ghannouchi 2016). This rebranding did little to win the confidence of non-Islamist Tunisians, however, and did not protect it from Saied's coup.

\section{Conclusions and Prospects}

Overall, then, the current conditions for Islamism are unusually bleak, with unprecedented challenges to mainstream political Islam at the regional, national, organizational, social, and ideological levels. There is no Islamist party currently doing well politically, and even those such as Ennahda and the PJD, which tried to moderate and appeal to a broader public, have fallen victim to the backlash. Key mechanisms that facilitated prior revivals are less available today. Islamist organizations have lost their reputational advantages, long-institutionalized organizations have been shattered, long-cultivated political strategies have failed, media advantages have faded, sources of external financing have dried up.

Islamists have passed through such difficult times in the past, however, and have proven resilient across multiple contexts. The likelihood of recurrent political instability, economic struggles, and failed governance across much of the region will likely present new opportunities for political mobilization. Most Arab states, at least outside the Gulf, offer plenty of areas of limited state capacity and overstretched social services. AntiIslamist polarization and the deep mistrust and even hatred toward Islamists among key sectors of activist youth and elites block new coalitions for now, but such passions could fade as conditions change and time moves on. The inherent political advantages of Islamist movements in Arab societies could potentially give them an upper hand in such turbulence, even if it is difficult to see them gaining significant purchase right now. The very polarization of the media, which blocks their efforts to rebrand with a broader public, could allow them to cultivate a stronger collective identity and purpose among their own subcultures. The longer that they remain in opposition, the more likely they can 
avoid identification with failed policies. This is an age of populism, and Islamists have long proven well-suited to capturing that sort of aggrieved anti-institutionalist anger.

Islamists are likely to prove resilient in the face of catastrophe, but their return to public life will likely take unfamiliar forms. Islamists, like their jihadist counterparts, have shown themselves able to adapt to new situations and to integrate other movements and organizations. Egypt's Muslim Brotherhood's revival in the 1970s was built in part on its assimilation of Islamist student groups. Syria's Muslim Brotherhood embedded itself within the mass civil uprising in 2011, giving the leadership abroad access to a mass base that it was no longer able to mobilize on its own. Jihadist insurgencies from Iraq to Lebanon to the Sahel grew by aligning themselves with existing societal organizations, from tribes and clans to criminal gangs (Lefèvre 2021; Thurston 2020). Given the wide span of grievances and the absence of compelling candidates for leadership across much of the region, an Islamist revival may well build upon such pragmatic alliances rather than solely the mobilization of an ideological cohort.

Their new incarnations may have much less clear a line separating them from jihadist movements that have evolved in the direction of normalization through their involvement in governance and politics (Ashour 2009; Hwang 2018; Drevon 2021). As civil wars die down, but resilient jihadist insurgencies remain in control of territory, they may evolve in a direction more open to collaboration with the remnants of Islam. The attempts at governance by the former al-Qaeda affiliate Hayat Tahrir al-Sham in the Idlib Province of Syria offers one example of such evolution (Drevon 2021; Drevon and Haenni 2021). To the extent that this happens, it could drive a convergence between Islamist models typically viewed as rivals - one that could offer a contrast with the more extreme jihadists consumed by internal ideological infighting. They may also be less clearly divided from their Salafi counterparts. The entry of many Salafi movements into electoral politics after 2011 blurred a key line between the two movements, and another line would blur should Muslim Brotherhood movements move back toward religious proselytizing as a way of adapting to political closure (Cavatorta and Merone 2016).

It is intriguing to compare the resilience of the Islamist movement to jihadist insurgencies, which have proven extremely resilient in almost every context where they have emerged. The continuing survival and efficacy of the Islamic State in Iraq and Syria, after years of the U.S.-led coalition's intense military campaign, attests to their ability to survive and adapt under the harshest of conditions. Islamic State franchises continue to emerge and fight effectively across diverse theaters, from Afghanistan to central Africa. Those insurgencies, however, are predominately localized despite the shared franchise and ideology (Thurston 2020). The shift from deterritorialized transnational terrorism to territorial insurgency is an epochal one for jihadism. Ideologically and strategically, it charts a trajectory from the national jihadist campaigns of the 1980s and 1990s through Bin Laden's and ISIS's global terrorist campaigns back to localized jihadist insurgency. These localized campaigns are identifiably jihadist of the IS variant, involving a particular ideological rhetoric and media production, governance of territories under their control, varying degrees of attraction of foreign fighters, and distinctive modes of warfare (Ashour 2021; Hashim 2018), but they also have pushed them in the direction of providing governance and, in a sense, their normalization within those spaces (Adraoui 2019). Syria, of course, has been the key incubator and laboratory for the evolution of these new jihadist formations (Abboud 2017; Baczko et al. 2018).

Where this intersects with political Islam's trajectory comprises the critical question of whether jihadists absorb and benefit from defections from political Islam or whether political Islam absorbs and benefits from the domestication of jihadist insurgencies. The destruction and repression of the Muslim Brotherhood in Egypt or Ennahda in Tunisia could, in principle, create a pool of ideologically mobilized recruits keen on revenge and eager to join violent jihadist alternatives, and the move to localized insurgency and governance could create conditions where those ex-Brothers could be useful and welcomed by evolving jihadist groups (Lia 2015). There are some historical precedents, such as 
Muslim Brothers in the 1980s becoming enthused by the Afghan jihad or Islamists after 2003 joining the resistance to the U.S. occupation of Iraq (Zelin 2020). The ideological drivers are both negative (the failure of political Islam's strategy almost everywhere in the region) and positive (the success of jihadist strategy in places like Afghanistan and Iraq/Syria). The extent to which this will happen remains unclear, however. The cadres of Muslim Brotherhood organizations have typically been middle class, socially integrated individuals who are not necessarily well-adapted to the rigors of jihadist insurgency. There are deep legacies of ideological disagreement and organizational hostility, as well as the legacies of indoctrination and training, which could deter defection in that direction. Finally, the religious doctrine and practices of the Islamic State milieu remain largely impenetrable to the average Muslim, even those from Brotherhood circles, but one can envision new hybrid forms of Islamism which take on a more confrontational strategy and more insular profile but within national and local contexts.

Funding: This research received no external funding.

Institutional Review Board Statement: Not applicable.

Informed Consent Statement: Not applicable.

Data Availability Statement: Not applicable.

Conflicts of Interest: The author declares no conflict of interest.

\section{References}

Abboud, Samer. 2017. Social Change, Network Formation and Syria's War Economies. Middle East Policy 24: 92-107.

Adraoui, Mohamed-Ali. 2019. The case of Jabhat Al-Nusra in the Syrian conflict 2011-2016: Towards a strategy of nationalization? Mediterranean Politics 24: 260-67. [CrossRef]

Al-Anani, Khalil. 2015. Upended Path: The Rise and Fall of Egypt's Muslim Brotherhood. The Middle East Journal 69: 527-43. [CrossRef]

Al-Anani, Khalil. 2016. Inside the Muslim Brotherhood: Religion, Identity, Politics. New York: Oxford University Press.

Al-Anani, Khalil. 2019. Rethinking the repression-dissent nexus: Assessing Egypt's Muslim Brotherhood's response to repression since the coup of 2013. Democratization 26: 1329-41. [CrossRef]

Ardovini, Lucia. 2021. Rethinking the Tanzim: Tensions Between Individual Identities and Organizational Factors in the Muslim Brotherhood after 2013. Middle East Law and Governance 13: 130-49. [CrossRef]

Ardovini, Lucia, and Erika Biagini. 2021. 10 Years On: New Contextual Factors in the Study of Islamism. Middle East Critique 30: 411-29. [CrossRef]

Ashour, Omar. 2009. The De-Radicalization of Jihadists: Transforming Armed Islamist Movements. New York: Routledge Press.

Ashour, Omar. 2021. How ISIS Fights. Edinburgh: Edinburgh University Press.

Baczko, Adam, Gilles Dorronsoro, and Arthur Quesnay. 2018. Civil War in Syria: Mobilization and Competing Social Orders. New York: Cambridge University Press.

Bayat, Asef. 2013. Post-Islamism: The Changing Faces of Political Islam. New York: Oxford University Press.

Brooke, Steven. 2018. Winning Hearts and Votes: Social Services and the Islamist Political Advantage. Ithaca: Cornell University Press.

Cammett, Melani, and Pauline Jones Luong. 2014. Is There an Islamist Political Advantage? Annual Review of Political Science 17: 187-206. [CrossRef]

Cavatorta, Francesco, and Fabio Merone, eds. 2016. Salafism After the Arab Awakening: Contending With People's Power. New York: Oxford University Press.

Cavatorta, Francesco, and Fabio Merone. 2013. Moderation through exclusion? The journey of the Tunisian Ennahda from fundamentalist to conservative party. Democratization 20: 857-75. [CrossRef]

Conduit, Dara. 2020. Syria's Muslim Brotherhood. New York: Cambridge University Press.

Daadaoui, Mohamed. 2021. Muslim Democrats: The Rise of Neo-Islamism in Morocco and Tunisia. British Journal of Middle East Studies, 1-12. [CrossRef]

Drevon, Jerome, and Peter Haenni. 2021. The Consolidation of a (Post-Jihadi) Technocratic State in Idlib. In MENA's Frozen Conflicts. POMEPS Studies. Washington, DC: POMEPS, vol. 42, pp. 42-47.

Drevon, Jerome. 2015. The Emergence of Ex-Jihadi Political Parties in Post-Mubarak Egypt. The Middle East Journal 69: 511-25. [CrossRef]

Drevon, Jerome. 2021. Can (Salafi) jihadi insurgents politicise and become pragmatic in civil wars? Social movement restraint in Ahrar al-Sham in Syria. Third World Thematics: A TWQ Journal, 1-17. [CrossRef]

Economist. 2019. Arabs Are Losing Faith in Religious Parties and Leaders. Economist, December 5. Available online: https: / / www.economist.com/graphic-detail/2019/12/05/arabs-are-losing-faith-in-religious-parties-and-leaders (accessed on 17 January 2022). 
Fahmi, George. 2017. Why aren't More Muslim Brothers Turning to Violence? Chatham House, April 27. Available online: https: //www.chathamhouse.org/expert/comment/why-aren-t-more-muslim-brothers-turning-violence (accessed on 17 January 2022).

Ghannouchi, Rashid. 2016. From Political Islam to Muslim Democracy: The Ennahda Party and the Future of Tunisia. Foreign Affairs 95: $58-69$.

Hashim, Ahmed S. 2018. The Caliphate at War: Operational Realities and Innovations of the Islamic State. New York: Oxford University Press.

Helfont, Samuel. 2018. Compulsion in Religion: Saddam Hussein, Islam, and the Roots of Insurgency in Iraq. New York: Oxford University Press.

Hwang, Julie Cherno. 2018. When Terrorists Quit: The Disengagement of Indonesian Jihadists. Ithaca: Cornell University Press.

Lacroix, Stephane. 2011. Islam Awakening. Cambridge: Harvard University Press.

Lefèvre, Raphaël. 2013. Ashes of Hama-The Muslim Brotherhood in Syria. London: Hurst.

Lefèvre, Raphaël. 2021. Jihad in the City. New York: Cambridge University Press.

Lia, Brynjar. 2015. Understanding Jihadi Proto-States. Perspectives on Terrorism 9: 31-41.

Lynch, Marc, and Jillian Schwedler. 2020. Islamist Movements After the Arab Uprisings. Middle East Law and Governance 12: 1-12.

Lynch, Marc. 2010. Islam Divided Between 'Salafi-jihad' and the 'Ikhwan'. Studies in Conflict E Terrorism 33: 467-87.

Lynch, Marc. 2016a. In Uncharted Waters: Islamist Parties Beyond Egypt's Muslim Brotherhood. Washington, DC: Carnegie Endowment for International Peace.

Lynch, Marc. 2016b. Is the Muslim Brotherhood a Terrorist Organization or a Firewall against Violent Extremism? In Evolving Methodologies in the Study of Islamism. POMEPS Studies. Washington, DC: POMEPS, vol. 17, pp. 6-9. Available online: https:/ / pomeps.org/wp-content/uploads/2016/03/POMEPS_Studies_17_Methods_Web.pdf (accessed on 17 January 2022).

Masoud, Tarek. 2014. Counting Islam: Religion, Class and Elections in Egypt. New York: Cambridge University Press.

Matthies-Boon, Vivienne. 2017. Shattered worlds: Political trauma amongst young activists in post-revolutionary Egypt. The Journal of North African Studies 22: 620-44. [CrossRef]

McCarthy, Rory. 2018a. When Islamists Lose: The Politicization of Tunisia's Ennahda Movement. The Middle East Journal 72: 365-84. [CrossRef]

McCarthy, Rory. 2018b. Inside Tunisia's Ennahda: Between Politics and Preaching. New York: Cambridge University Press.

Medani, Khalid. 2021. Black Markets and Militias. New York: Cambridge University Press.

Mellor, Noha. 2021. The Making of the Muslim Brotherhood's Faith Brand. Middle East Law and Governance 13: 196-214. [CrossRef]

Menshawy, Mustafa. 2021. The Ideology Factor and Individual Disengagements from the Muslim Brotherhood. Religions 12: 198. [CrossRef]

Nugent, Elizabeth. 2020. After Repression. Princeton: Princeton University Press.

Pahwa, Sumita. 2017. Pathways of Islamist adaptation: The Egyptian Muslim Brothers' lessons for inclusion moderation theory. Democratization 24: 1066-84. [CrossRef]

Schwedler, Jillian. 2011. Can Islamists Become Moderates?: Rethinking the Inclusion-Moderation Hypothesis. World Politics 63: 347-76. [CrossRef]

Thurston, Alexander. 2020. Jihadists of North Africa and the Sahel: Local Politics and Rebel Groups. New York: Cambridge University Press. Wagemakers, Joas. 2020. The Muslim Brotherhood in Jordan. New York: Cambridge University Press.

Wagemakers, Joas. 2021. Things Fall Apart: The Disintegration of the Jordanian Muslim Brotherhood. Religions 12: 1066. [CrossRef] Willi, Victor. 2021. The Fourth Ordeal. New York: Cambridge University Press.

Wolf, Anne. 2017. Political Islam in Tunisia: The History of Ennahda. New York: Oxford University Press.

Zelin, Aaron. 2020. Our Sons Are at Your Service: Tunisia's Missionaries of Jihad. New York: Columbia University Press.

Zollner, Barbara. 2008. The Muslim Brotherhood: Hassan al-Hudaybi and Ideology. New York: Routledge.

Zollner, Barbara. 2019. Surviving Repression. How Egypt's Muslim Brotherhood has Carried on. Carnegie Endowment for International Peace, March 11. Available online: https: / / carnegie-mec.org/2019/03/11/surviving-repression-how-egypt-s-muslimbrotherhood-has-carried-on-pub-78552 (accessed on 17 January 2022). 